Dhaka Univ. J. Biol. Sci. 28(2): 147-158, 2019 (July)

\title{
INVESTIGATION OF SURFACE WATER QUALITY OF THE BURIGANGA RIVER IN BANGLADESH: LABORATORY AND SPATIAL ANALYSIS APPROACHES
}

\author{
Mohammad Saiful Islam*, Romana Afroz and Md. Bodruddoza Mia \\ Department of Geology, University of Dhaka, Dhaka-1000, Bangladesh
}

Key words: Surface water quality, Buriganga river, Laboratory and spatial analysis

\begin{abstract}
This work has been conducted to evaluate the water quality of the Buriganga river. In situ water quality parameters and water samples were collected from 10 locations in January 2016 and analyzed later in laboratory for water quality parameters such as $\mathrm{pH}, \mathrm{Eh}, \mathrm{EC}$, TDS, cations $\left(\mathrm{Na}^{+}, \mathrm{K}^{+}, \mathrm{Ca}^{2+}, \mathrm{Mg}^{2}\right.$, $\left.\mathrm{As}^{3+}\right)$, anions $\left(\mathrm{Cl}^{-}, \mathrm{HCO}_{3}^{-}, \mathrm{NO}_{2}{ }^{-}, \mathrm{NO}_{3}{ }^{-}, \mathrm{SO}_{4}{ }^{2-}, \mathrm{F}^{-}, \mathrm{Br}^{-}, \mathrm{PO}_{4}{ }^{3-}\right)$, heavy metals $\left(\mathrm{Cr}^{2+}\right.$, $\left.\mathrm{Pb}^{2+}, \mathrm{Zn}^{2+}, \mathrm{Cd}^{+2}, \mathrm{Fe}^{2+}, \mathrm{Mn}^{2+}\right)$ to see whether or not the level of these parameters are within the permissible limits. The average values of $\mathrm{pH}, \mathrm{Eh}, \mathrm{EC}$ and temperature were $7.31,-214.9 \mathrm{mV}, 928.9 \mu \mathrm{s} / \mathrm{cm}$ and $21.4^{\circ} \mathrm{C}$, respectively; the average concentration of $\mathrm{Na}^{+}, \mathrm{K}^{+}, \mathrm{Ca}^{2+}, \mathrm{Mg}^{2+}$, and $\mathrm{As}^{3+}$ were 109.62, 13.38, 46.78, 13.98 and $0.018 \mathrm{mg} /$, respectively, while the concentrations of $\mathrm{Cl}^{-}, \mathrm{HCO}_{3}^{-}, \mathrm{PO}_{4}^{3-}$, $\mathrm{SO}_{4}{ }^{2-}, \mathrm{NO}_{3}{ }^{-}, \mathrm{NO}_{2}{ }^{-}, \mathrm{F}$ and $\mathrm{Br}$-were 79, 331.06, 2.22, 84.32, 0.0254, 0.058, 0.224 and $0.073 \mathrm{mg} /$, respectively; and the concentration of heavy metals $\mathrm{Pb}^{2+}, \mathrm{Zn}^{2+}, \mathrm{Fe}^{2+}$ and $\mathrm{Mn}^{2+}$ were $0.28,0.053,0.17$ and $0.23 \mathrm{mg} \Lambda$, respectively. The study indicates that most of the parameters are within the permissible limits set by Bangladesh water quality standard. The concentrations of $\mathrm{K}^{+}, \mathrm{Mn}^{2+}$, and $\mathrm{Pb}^{2+}$ were beyond the permissible limits meaning that that the water of Buriganga is not safe for drinking. The people living beside Buriganga river should be more cautious about using the polluted/contaminated river water. The concerned authorities should take urgent necessary steps to improve the degraded water quality of the river considering the ecological, environmental and economic implications associated with it.
\end{abstract}

\section{Introduction}

Bangladesh is the largest delta of the world with its 230 rivers flowing all over the country like a net. Although Bangladesh is predominantly a plain surface, it is crisscrossed by a very high density river system. For centuries, the river system has been a major part of the civilization in this part of the world. It is also a vital part of our environment. The aquatic ecosystem is closely integrated with these rivers. Moreover, in Bangladesh, the environment, economic growth and developments are all highly influenced by water - its regional and seasonal availability and the quantity of surface and groundwater ${ }^{(1)}$.

*Author for correspondence: <msaiful@du.ac.bd>. 
Buriganga river is originated from Dhaleshwari near Kalatia passing through west and south of Dhaka city, the capital of Bangladesh (2). It is one of the most important rivers around Dhaka city with respect to irrigation, fisheries, transportation, and also for recreation. Buriganga river also plays a very vital role for supplying drinking water and balancing the environment of the densely populated Dhaka city. Nowadays, the Buriganga river is overwhelmed by the pollution from sewerage and industrial effluents. It is considered as one of the most polluted rivers in Bangladesh ${ }^{(3)}$. The Buriganga river water has been changing in terms of its quantity and quality(2). The rapid development of industrialization, urbanization and other development activities around the Buriganga river are mainly responsible for the deterioration of water quality and reduction of water quantity $(2,4)$. As most of the textile and garments-cum dying factories are situated on the bank of the Buriganga, they discharge heavy loads of both liquid and solid wastes into the river without treatment (5). Besides, the urban sewage of the city is also being added to the river. This huge amount of effluents and solid wastes are getting mixed with the river water and sediments every day; more than 60,000 cubic meters $(2,100,000$ cubic feet) of toxic wastes from these sources are being discharged into the main water bodies of the river(6). We measured in situ water quality parameters such as Eh, pH, EC and collected water samples from different locations through field work and later on analyzed various qualitative parameters of river water in the laboratory. One of the prime objectives of this study is to investigate the water quality of the Buriganga river in the year of 2016. The other target is to assess the qualitative parameters of Buriganga river water using GIS spatial analysis with support of ground in situ data.

The Buriganga river flows around the southwest outskirts of Dhaka city. The maximum and average depth of the river are about 18 and $7.6 \mathrm{~m}$, respectively, and its length is about $18 \mathrm{~km}^{(6)}$. The Buriganga river encompasses the south-western periphery of Dhaka City (7). In the distant past, a course of the Ganges river used to reach the Bay of Bengal through the Dhaleshwari river. When this course gradually shifted and ultimately lost its link with the main channel of the Ganges it was renamed as the Buriganga. The main flow of the Buriganga river comes from the Turag river. The area is surrounded by the residential areas on all of its sides. Our study area comprises an area of 1411.47 hectares (Fig. 1). The extent of the study area is from $90^{\circ} 20^{\prime} 09.46^{\prime \prime} \mathrm{E}$ to $90^{\circ} 26^{\prime} 59.14^{\prime \prime} \mathrm{E}$ longitude and $23^{\circ} 37^{\prime} 36.22^{\prime \prime} \mathrm{N}$ to $23^{\circ} 47^{\prime} 08.27^{\prime \prime} \mathrm{N}$ latitude. Rapid urbanization without considering the geological aspects has resulted in significant changes in the geoenvironment of the study area. Waterlogging, pollution, changes in the hydrogeological system, localized land subsidence and building collapse are the hazards associated with these changes in the geo-environment. 


\section{Materials and Methods}

Field investigation is important for evaluating any parameter of water quality. To conduct this work, ten water samples were collected from Buriganga river from ten different locations (upstream to downstream) (Fig. 2). Field works were conducted within the study area with sophisticated instruments such as handheld GPS, HANNA Pocket $\mathrm{pH}$ and Eh meter (model HI 98127), OAKTON waterproof pocket $\mathrm{pH}-\mathrm{EC}$ comb. Meter (Model PC tester 35).

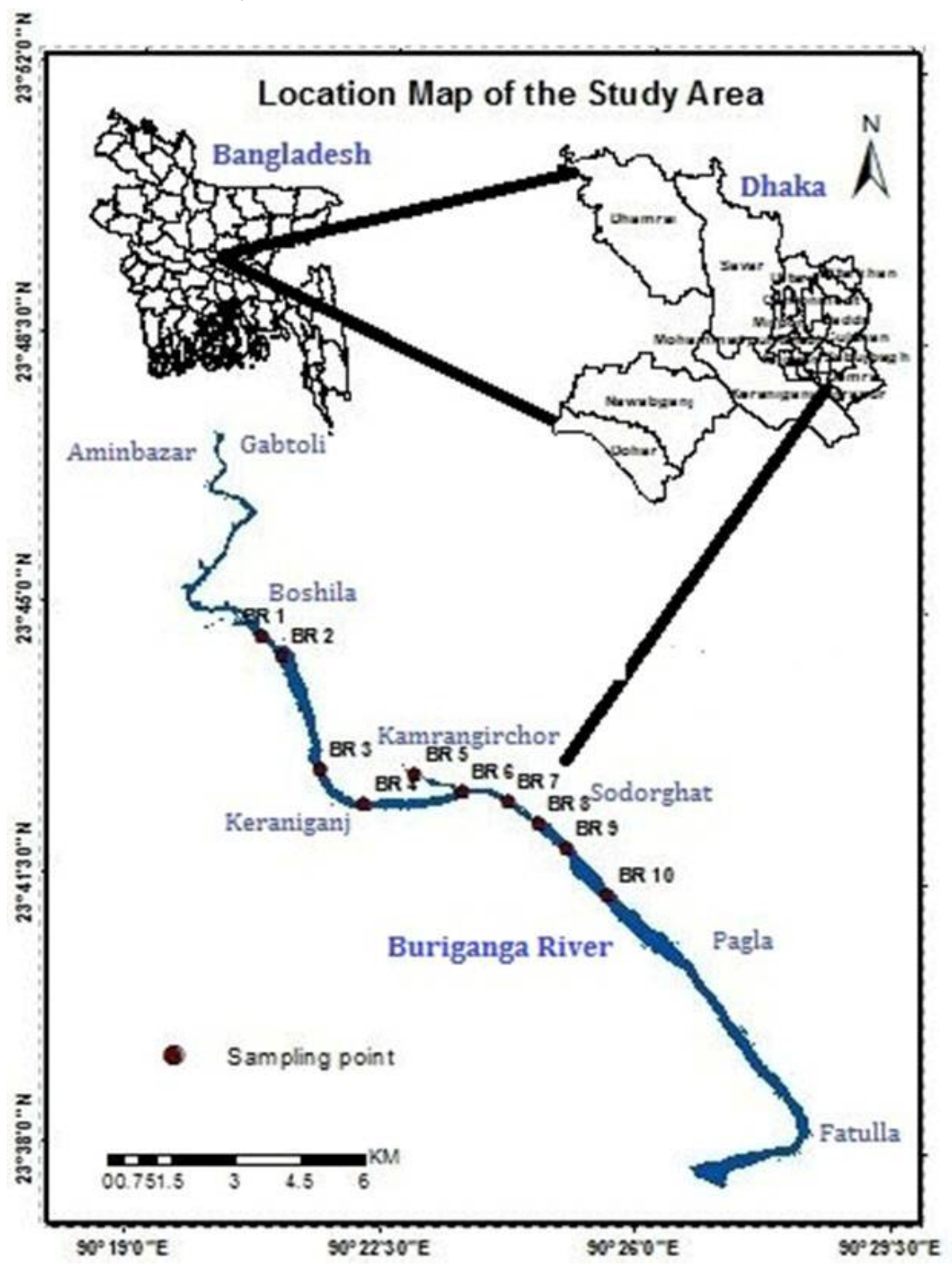

Fig. 1. Location map of the study area. 


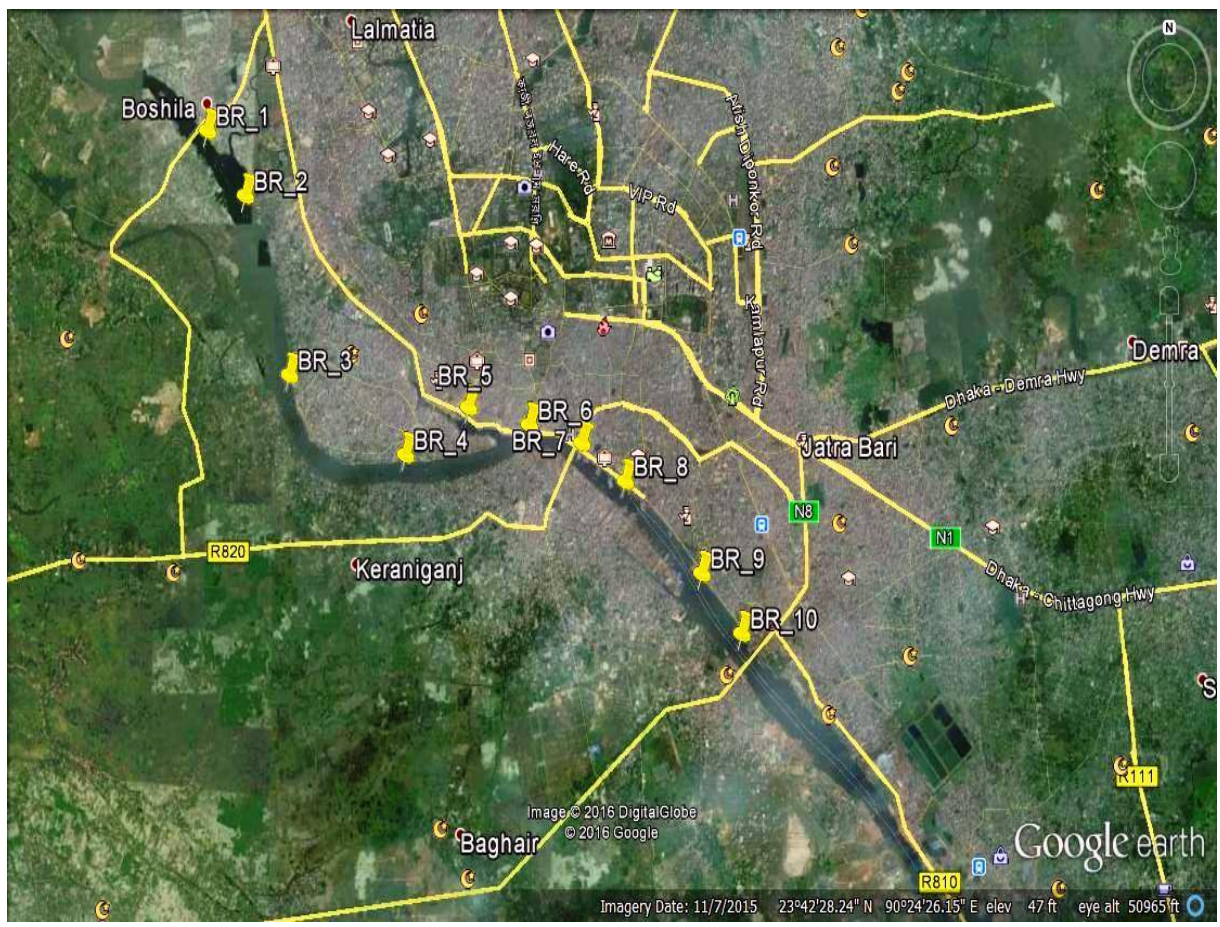

Fig. 2. Water sampling locations of the study area(8).

Two $125 \mathrm{ml}$ PVC bottles were used for sampling. During sampling $0.45 \mu \mathrm{m}$ membrane filters were used to filter water samples in order to remove colloidal materials and other unwanted particles. One bottle of sample was acidified using concentrated $\mathrm{HNO}_{3}$ to lower the $\mathrm{pH}$ value to $<3$ to avoid precipitation of the dissolved constituents from the samples. Sampling process was started by rinsing the sample bottles three times with the filtered water; then two-third of the $125 \mathrm{ml}$ sample bottle was filled with the filtered water and it was acidified with concentrated $\mathrm{HNO}_{3}$ and then the rest of the bottle was filled up leaving no empty space. Physico-chemical parameters like $\mathrm{pH}$, Eh, electrical conductivity (EC), total dissolved solid (TDS) and temperature were measured in the field. Different methods were applied for determining the concentration of different chemical constituents of the sample waters; flame photometer (Jenway PFP-7) wavelength $769 \mathrm{~nm}$ for $\mathrm{Na}$ and $\mathrm{K}^{(9,10)}$; atomic absorption spectrometer (GBC SensAA) for $\mathrm{Ca}, \mathrm{Mg}, \mathrm{Fe}$ and $\mathrm{Mn}$ and other heavy metals (11); titration method for $\mathrm{HCO}_{3}$ and $\mathrm{Cl}^{(12)}$; UVVisible spectro-photometer (T60 PG) wavelength $410 \mathrm{~nm}$ for $\mathrm{NO}_{3}$ and $\mathrm{SO}_{4}{ }^{(11)}$. ArcGIS software was used for preparing maps such as location map and spatial distribution map. Rock Works 15 software was employed for piper diagram which describes hydrochemical facies analyses ${ }^{(13)}$. 


\section{Results and Discussion}

In the study area, the value of $\mathrm{pH}$ ranged from 6.88 to 7.60 and the average value were 7.31 which indicate that the river water was more or less neutral in character (Fig. $3 \mathrm{~A})$. The highest value of $\mathrm{pH}$ was 7.60 near Sadarghat boat terminal. The water samples were collected in January and at that time the volume of water was low. The value was high due to high base saturations with low volume of water. Tannery industries effluent discharged without any treatment might have contributed too. The lowest value of $\mathrm{pH}$ was 6.88 near Kamrangirchor Bridge (Fig. 3A). According to United States Environmental Protection Agency (USEPA), World Health Organization (WHO) and Department of Environment of Bangladesh(DoE), the standard $\mathrm{pH}$ value for Drinking water is from 6.5 to $8.5^{(14,15,16)}$. So all these $\mathrm{pH}$ values at different locations were within the permissible limit for drinking purpose. The Eh value from upstream to downstream was -94 to $-250 \mathrm{mV}$ and the average value was $-214.9 \mathrm{mV}$ (Fig. 3B). The highest value was $-250 \mathrm{mV}$ near Kamrangirchor Bridge and the lowest value was $-94 \mathrm{mV}$ near Sahid Buddhizibi Bridge road (Fig. 3B). The negative value indicates that the environment was reducing.

$\mathrm{EC}$ is an estimate of the total amount of dissolved ions in the water. The EC values of Buriganga river ranged from 860 to $1018 \mu \mathrm{s} / \mathrm{cm}$ and the average value was $928.9 \mu \mathrm{s} / \mathrm{cm}$ (Fig. 3C). The highest value of EC was recorded near Kamrangirchor Bridge and the lowest value was recorded near Shahid Buddhizibi Bridge road (Fig. 3C). It is known that in January (dry season) the river flow decreases. As a result EC increases ${ }^{(17,18)}$. Nevertheless, these values indicate that the river Buriganga might have received wastewater (industrial and sewage effluent) which contained high ionic concentration. The value of EC of a water body greater than $1000 \mathrm{mg} /$ is not suitable for agricultural, household,bathing and drinking purposes ${ }^{19)}$. So, EC value is within the range, but near Kamrangichor Bridge, the value of EC is not within the limit due to the discharge of tannery effluent and metal plating industries. The investigated value of temperature was about $21.9^{\circ} \mathrm{C}$ where the maximum value was $24.4^{\circ} \mathrm{C}$ and the minimum value was $20.4^{\circ} \mathrm{C}$. From the analysis, it was found that the water was hard and the hardness value in every sample exceeded the limit set by WHO where the standard value of hardness for drinking water is 0 to $75 \mathrm{mg} /$. The maximum value was $204.88 \mathrm{mg} /$ in water. The concentration of arsenic was between 0.009 and $0.027 \mathrm{mg} /$ with a mean value of 0.018 $\mathrm{mg} /$ (Fig. 3C). According to WHO, USEPA and DoE, the standard of arsenic is 0.01, 0.01 and $0.05 \mathrm{mg} \Lambda$, respectively. So, the concentration of arsenic in the analyzed samples was within the limits.

The distribution of ions in the study area showed wide variations. The charge balance between cations and anions was within acceptable limits (less than 10\%) confirming the reliability of the analytical results (20). Among the anions, $\mathrm{HCO}_{3}^{-}$was dominant and the concentration was between 318 and $357.125 \mathrm{mg} /$ with a mean value of 331.06 mg/ (Fig. 4). The highest value was near Kamrangirchor Bridge. Chloride varied 
between 67.72 and $105.96 \mathrm{mg} /$ with a mean value of $79 \mathrm{mg} /$ (Fig. 4). According to WHO, the standard concentration of $\mathrm{Cl}^{-}$for drinking water is $250 \mathrm{mg} /$ and according to DoE, the value is $150-600 \mathrm{mg} A$ and below this limits it is not proper for drinking purpose and
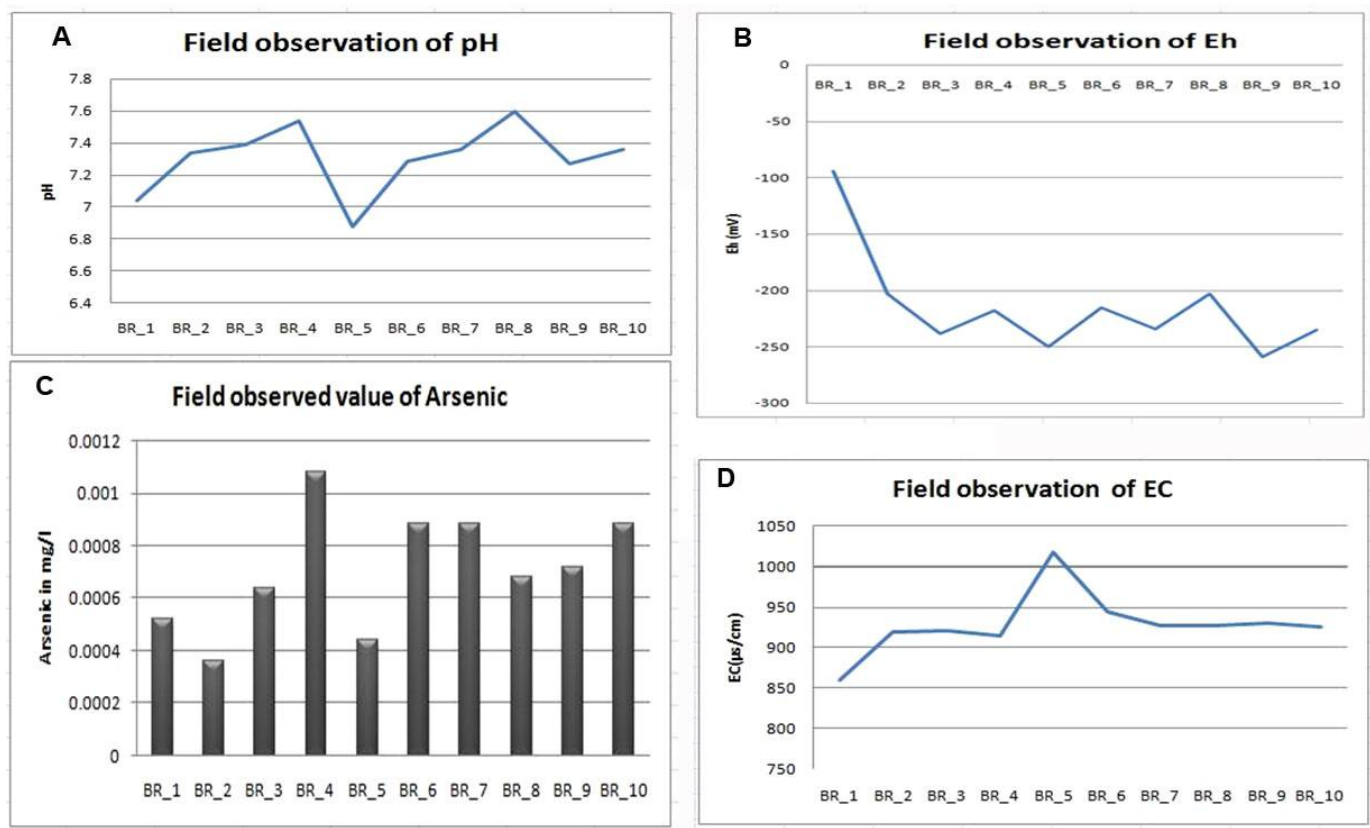

Fig. 3. In situ physical properties of the Buriganga river in 10 sampling points.

in this analysis $\mathrm{Cl}^{-}$was beyond this limit $(15,16)$. The $\mathrm{PO}_{4}^{3-}$ levels ranged from 0.94 to 5.62 $\mathrm{mg} /$ with a mean value of $2.22 \mathrm{mg} /$. The concentration of $\mathrm{SO}_{4}{ }^{2-}$ ranged from 21.57 to 110.72 with a mean value of $84.32 \mathrm{mg} \Lambda$ and it was within the limit. Nitrate concentration was between 0.016 and $0.058 \mathrm{mg} /$ with a mean value of $0.0254 \mathrm{mg} /$ and was also within the limit. Besides the major anions there were some other anions. Flouride concentration ranged from 0.2 to $0.25 \mathrm{mg} /$ with a mean value of $0.224 \mathrm{mg} /$. According to USEPA, WHO and DoE, the standard of F- is $2,1.5$ and $1 \mathrm{mg} \Lambda$, respectively and from the analysis it is found that it was within the limit. The concentration of $\mathrm{Br}^{-}$was between 0.033 and $0.21 \mathrm{mg} /$ with a mean value to $0.073 \mathrm{mg} /$. Nitrite was found in only one sample near Postogola Bridge and the concentration was $0.058 \mathrm{mg} A$. According to USEPA and WHO, the maximum contamination level of nitrite is 10 and $50 \mathrm{mg} A$, respectively and the nitrite concentration was within the limit.

Among the cations, $\mathrm{Na}^{+}$concentration was high and the concentrations were between 92.9 and $118.16 \mathrm{mg} /$ with a mean of $109.62 \mathrm{mg} /$ (Fig. 5). The higher concentration of sodium may have resulted from the sodium-rich effluent from nearby chemical, food, tannery and leather industries. According to DoE, the standard value of $\mathrm{Na}^{+}$is $200 \mathrm{mg} \Lambda$ and the values are within the limit ${ }^{(15)}$. The concentration of $\mathrm{Ca}^{2+}$ was between 40.62 and 
$54.37 \mathrm{mg} /$ with a mean value of $46.78 \mathrm{mg} /$. The concentration of $\mathrm{Mg}^{2+}$ was between 12.15 and $16.78 \mathrm{mg} \Lambda$ with a mean value of $13.98 \mathrm{mg} \Lambda$ (Fig. 5). The $\mathrm{K}^{+}$levels ranged from 12.58

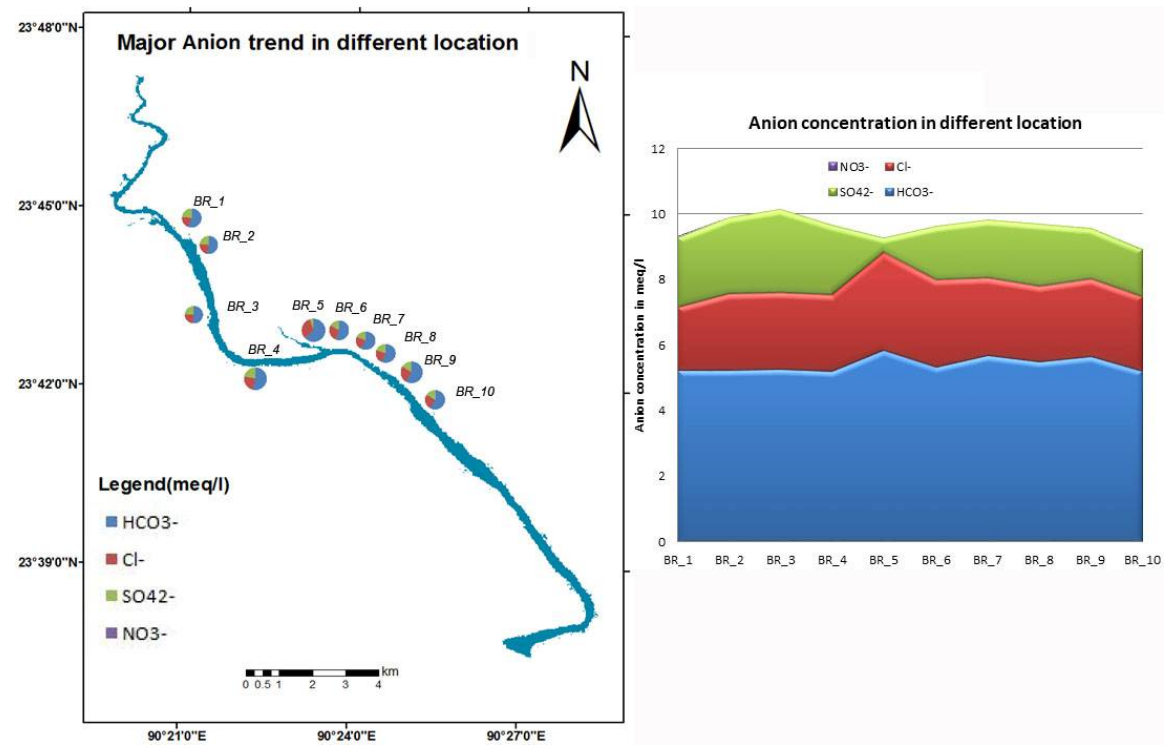

Fig. 4. Major anion concentration and its trend in the water bodies of the Buriganga river.

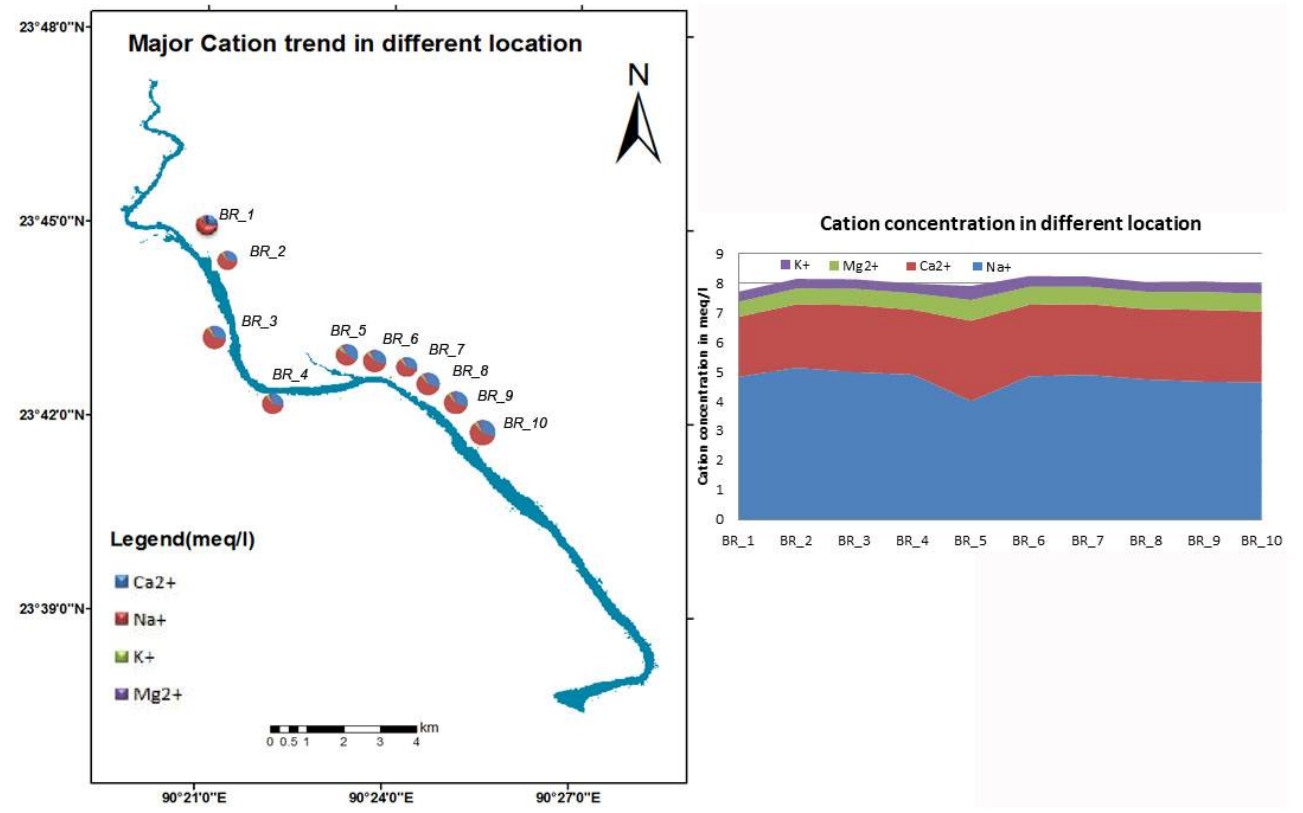

Fig. 5. Major cation concentration and its trend in the water bodies in the Buriganga river. 
to $18.6 \mathrm{mg} /$ with a mean value of $13.83 \mathrm{mg} /$ which was beyond the limit. From the piper diagram, two types of mixed water have been found: one is $\mathrm{Na}-\mathrm{Ca}-\mathrm{HCO}_{3}-\mathrm{SO}_{4}-\mathrm{Cl}$ type and the other one is $\mathrm{Na}-\mathrm{Ca}-\mathrm{HCO}_{3}-\mathrm{Cl}$ type (Fig. 6, Table 1) ${ }^{(13)}$. Results of another study showed that in both the dry and wet periods, Buriganga river water are of $\mathrm{Ca}-\mathrm{HCO}_{3}$ type (21). According to $\mathrm{WHO}$, the standard value of hardness for drinking water is 0 to $75 \mathrm{mg} /$ but, from the analysis, the Buriganga river water was found to be hard as it exceeded the standard limit ${ }^{(16)}$.

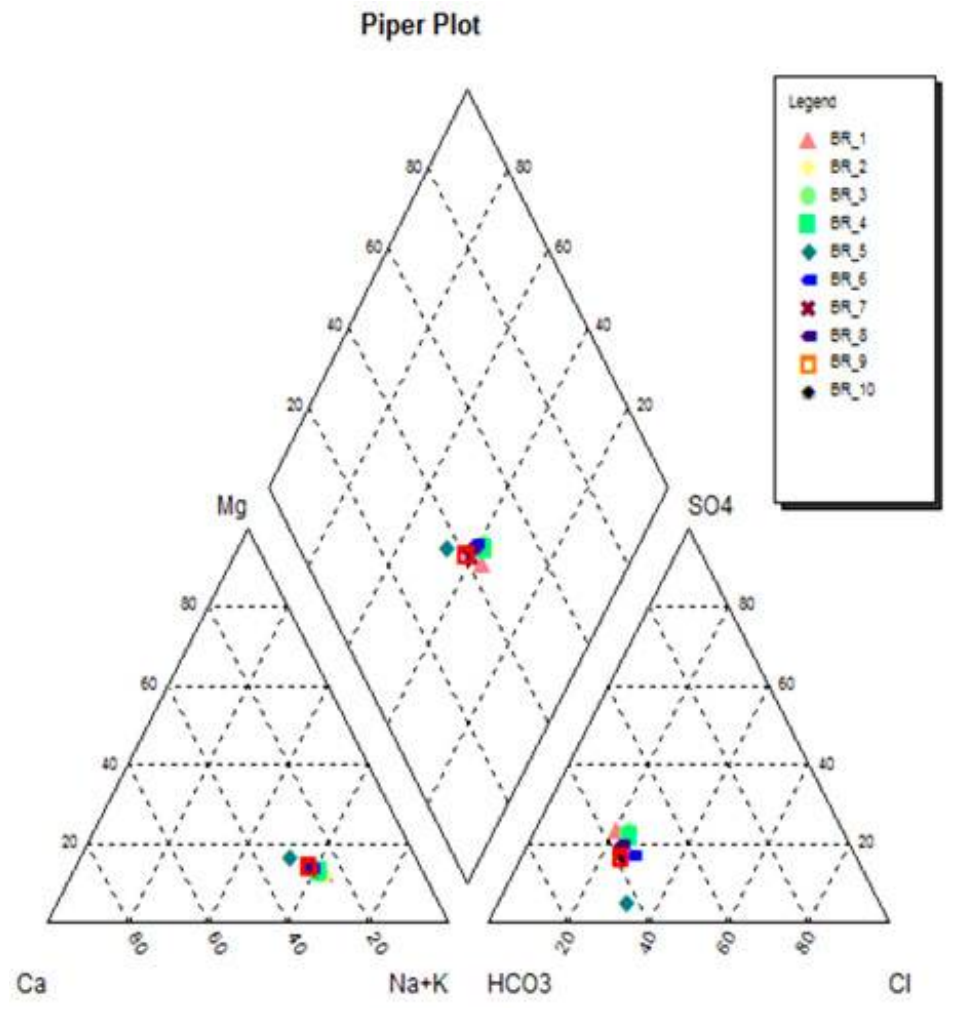

Fig. 6. Piper diagram of collected water samples from the Buriganga river(13).

The concentrations of six heavy metals, namely iron, manganese, zinc, lead, chromium and cadmium, were determined in the laboratory. The concentration of $\mathrm{Fe}^{2+}$ ranged between 0.08 and $0.28 \mathrm{mg} /$ with a mean value of $0.17 \mathrm{mg} /$ which is considered to be safe for drinking purpose (Fig. 7). Many pharmaceuticals, chemical and pesticides industries are located around the study area from which iron could come into the water. The $\mathrm{Mn}^{2+}$ levels were between 0.14 and $0.26 \mathrm{mg} /$ with a mean value of $0.23 \mathrm{mg} /$, which exceeded the limit of DoE and WHO and not safe for drinking(15,16). The analyzed concentration of $\mathrm{Zn}^{2+}$ was between 0.04 and $0.084 \mathrm{mg} /$ with a mean value of $0.053 \mathrm{mg} \Lambda$. According to $\mathrm{WHO}$, the standard concentration for zinc is from 3 to $5 \mathrm{mg} \Lambda$ and in the study area it is below the permissible level. The lower level of zinc could be attributed to 
the precipitation of $\mathrm{Zn}$ as $\mathrm{ZnCO}_{3}$. Total lead concentrations in the analyzed water samples varied and all the samples exceeded the DoE standard as the concentration of total $\mathrm{Pb}^{2+}$ varied between 0.035 and $0.845 \mathrm{mg} \Lambda$ with a mean of $0.28 \mathrm{mg} /$. The values increased from upstream to downstream. Chromium was within the acceptable limit in all the water samples, coming from painting industries and also from leather industries. Cadmium was also found to be within the acceptable level.

Table 1. The water properties found from Piper diagram ${ }^{(13)}$.

\begin{tabular}{llcc}
\hline $\begin{array}{l}\text { Sample } \\
\text { ID }\end{array}$ & $\begin{array}{l}\text { Water } \\
\text { type }\end{array}$ & $\begin{array}{c}\text { Total hardness } \\
\left(\mathrm{mg} / \mathrm{CaCO}_{3}\right)\end{array}$ & $\begin{array}{c}\text { Alkalinity } \\
\left(\mathrm{mg} / \mathrm{CaCO}_{3}\right)\end{array}$ \\
\hline BR_1 & $\mathrm{Na}-\mathrm{Ca}-\mathrm{HCO}_{3}-\mathrm{SO}_{4}-\mathrm{Cl}$ & 152.48 & 262.70 \\
BR_2 & $\mathrm{Na}-\mathrm{Ca}-\mathrm{HCO}_{3}-\mathrm{Cl}-\mathrm{SO}_{4}$ & 159.60 & 262.56 \\
BR_3 & $\mathrm{Na}-\mathrm{Ca}-\mathrm{HCO}_{3}-\mathrm{Cl}-\mathrm{SO}_{4}$ & 167.85 & 263.59 \\
BR_4 & $\mathrm{Na}-\mathrm{Ca}-\mathrm{HCO}_{3}-\mathrm{Cl}-\mathrm{SO}_{4}$ & 164.63 & 260.82 \\
BR_5 & $\mathrm{Na}-\mathrm{Ca}-\mathrm{HCO}_{3}-\mathrm{Cl}$ & 204.88 & 292.91 \\
BR_6 & $\mathrm{Na}-\mathrm{Ca}-\mathrm{HCO}_{3}-\mathrm{Cl}$ & 180.78 & 266.66 \\
BR_7 & $\mathrm{Na}-\mathrm{Ca}-\mathrm{HCO}_{3}-\mathrm{Cl}$ & 177.96 & 285.78 \\
BR_8 & $\mathrm{Na}-\mathrm{Ca}-\mathrm{HCO}_{3}-\mathrm{Cl}-\mathrm{SO}_{4}$ & 176.57 & 275.07 \\
BR_9 & $\mathrm{Na}-\mathrm{Ca}-\mathrm{HCO}_{3}-\mathrm{Cl}$ & 181.30 & 283.68 \\
BR_10 & $\mathrm{Na}-\mathrm{Ca}-\mathrm{HCO}_{3}-\mathrm{Cl}$ & 178.94 & 261.64 \\
\hline
\end{tabular}

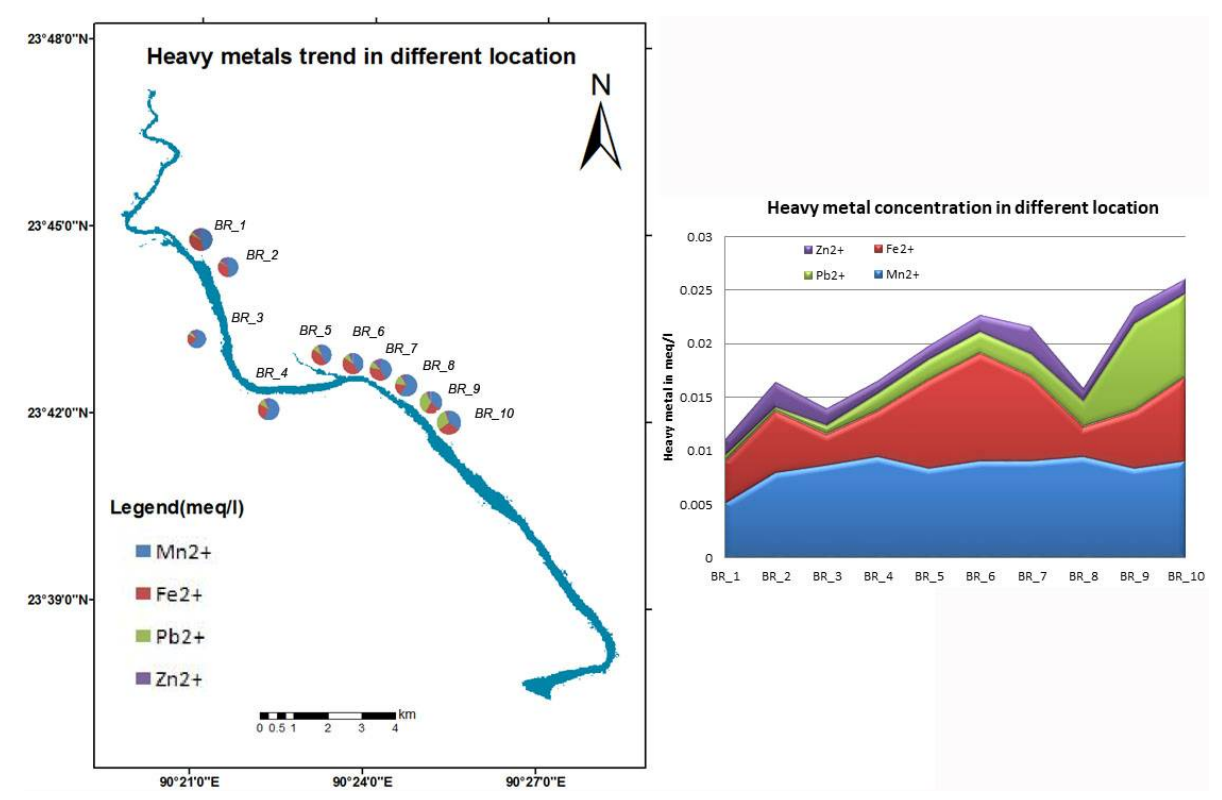

Fig. 7. Major heavy metal concentrations and its trend in the Buriganga river. 
The TDS value ranged from 655 to $708 \mathrm{mg} /$ and the average value was $687.50 \mathrm{mg} \Lambda$ (Fig. 8). The highest value was near Aganagar Nodidhara Ghat, Keraniganj and the lowest value was near Postogola bridge. According to WHO, the maximum limit of TDS

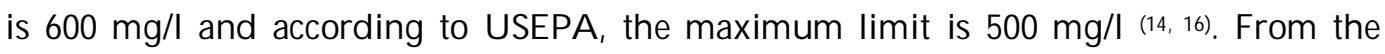
present study it is found that all the samples crossed the limit which indicates a bad condition of the river. The water is certainly not safe for drinking purposes; but according to DoE, the value is $1000 \mathrm{mg} \Lambda$, which implies that all the samples were within the limit. As it is known that the Buriganga river is surrounded by many industries, particularly tanneries, the tannery effluents are discharged without treatment and this makes the water more turbid and saline that has a detrimental effect on aquatic lives and, if applied in soil as irrigation water, the water may affect the crops as well.

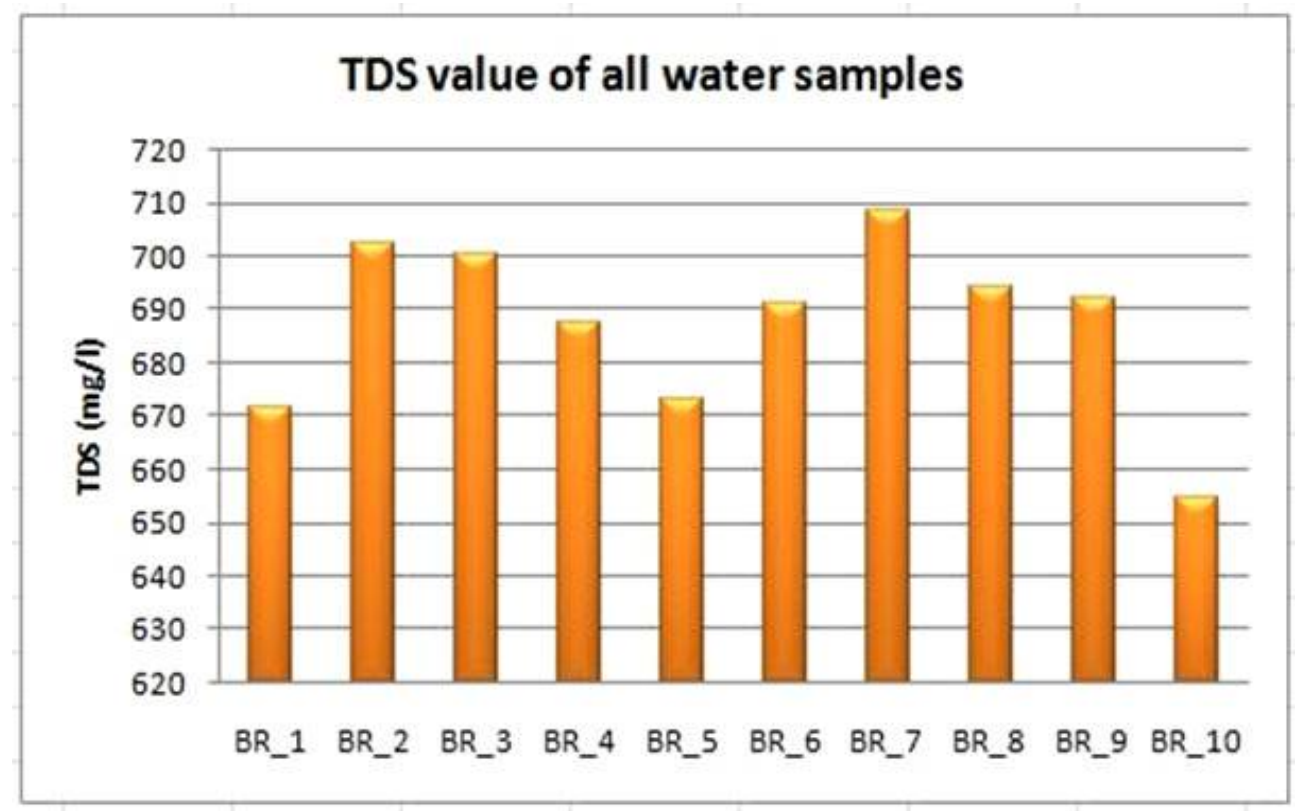

Fig. 8. Diagram showing the values of TDS in different location from upstream to downstream.

It is known that the water quality of Buriganga river has been degrading day by day but from data analysis in this study, it is found that some parameters are within the permissible limit set by DoE and WHO. Some of the parameters of the river water are beyond the limits. The acceptable water quality parameters are $\mathrm{pH}, \mathrm{Eh}, \mathrm{EC}$, temperature, cations $\left(\mathrm{Na}^{+}, \mathrm{Ca}^{2+}, \mathrm{Mg}^{2+}, \mathrm{As}^{3+}\right)$, anions $\left(\mathrm{HCO}_{3}, \mathrm{PO}_{4}^{3-}, \mathrm{SO}_{4}{ }^{2-}, \mathrm{NO}_{3}-\mathrm{NO}_{2}, \mathrm{~F}-\mathrm{Br}-\right)$ and heavy metals $\left(\mathrm{Fe}^{2+}, \mathrm{Zn}^{2+}\right)$. The parameters found beyond the permissible limits are $\mathrm{K}^{+}, \mathrm{Mn}^{2+}, \mathrm{Pb}^{2+}$. Among all the parameters, $\mathrm{Cl}^{-}$is the only element that was beyond the limit of $\mathrm{WHO}$ and DoE, which means that the water is not safe for drinking. Near Kamrangirchor bridge, 
the value of EC was high $(1018 \mu \mathrm{S} / \mathrm{cm})$ due to the discharge of tannery effluent and metal plating industries.The Buriganga river is not only the lifeline of the capital city but also a perennial source of natural beauty for the common people of the country. The present state of water pollution has given rise to an unhealthy environment of the city. It has now become an urgent issue for the concerned authority to undertake some comprehensive and holistic approaches to save this river.

\section{Acknowledgements}

Authors deeply acknowledge the Ministry of Science and Technology, Government of Bangladesh for funding this research project.

\section{References}

1. Ali, MY, MN Amin and K Alam 2008. Ecological Health Risk of Buriganga River, Dhaka, Bangladesh. Hydro Nepal: Journal of Water, Energy and Environment 3: 1-4.

2. Saifullah, SM, MH Kabir, A Khatun, S Roy and MS Sheikh 2012. Investigation of some water quality parameters of the Buriganga River. J. of Environ. Sci. \& Natural Resources 5(2): 4752.

3. Sarkar, M., AKML Rahman, JB Islam, KS Ahmed, MN Uddin and NC Bhoumik 2015. Study of hydrochemistry and pollution of Buriganga River, Bangladesh. Bangladesh J. Sci. Ind. Res.50(2): 123-134.

4. Islam, MM, MK Akhtar and MS Masud 2006. Prediction of environmental flow to improve the water quality in the river Buriganga. In: Proceedings of the 17th IASTED International Conference on Modelling and Simulation, Montreal, QC, Canada.

5. Ahmed, MK, M Das, MM Islam, MS Akter, S Islam and MA Al-Mansur 2011. Physico-chemical properties of tannery and textile effluents and surface water of river Buriganga and Karnatoli, Bangladesh. World Applied Sciences Journal 12(2): 152-159.

6. Chowdhury, SQ 2012. Buriganga River. In: Islam, Sirajul and Ahmed Jamal. Banglapedia: National Encyclopedia of Bangladesh (Second ed.). Asiatic Society of Bangladesh.

7. Islam, N 2005. Dhaka now: contemporary development. Dhaka, the Bangladesh Geographical Society.

8. Google Earth image, 2016.

9. Michael, AM 1992. Irrigation Theory and Practices. Vikas Publishing House Ltd., New Delhi, p. 740 .

10. Misra, RD and M Ahmed 1987. Manual on Irrigation Agronomy. Oxford and IBH Publishing Co. Pvt. Ltd., New Delhi. p. 248-271.

11. Page, AL 1982. Methods of soil analysis (ed). Part 2 Am. Soc. Agron-Soil Sci. Am. Madison, Wis. USA. p. 159-446.

12. Jackson, ML 1967. Soil Chemical Analysis. Prentice Hall Inc. Englewood Cliffs. NJ. USA. p 227-267.

13. Piper, AM 1953. A graphic procedure in the geochemical interpretation of water analysis, USGS Groundwater note No. 12. p. 13. 
14. USEPA 1995. Quality criteria for water. Washington, D.C. p. 501.

15. DoE 1997. Environmental Quality Standard for Bangladesh. Bangladesh Gazette, Department of Environment, Ministry of Environment and Forest. Government of Bangladesh. DA-1. p. 3124-4134.

16. WHO 2004. Guideline for drinking water Quality, Vol. 1 \& 2 World Health Organization.

17. Hem JD 1989. Study and interpretation of the chemical characteristics of natural water. 3rd edition, USGS WSP2254, Washington, D.C., pp.263.

18. Matthess, G 1982. The Properties of Groundwater. John Wiley \& Sons, New York, Chichester, Brisbane, Toronto, Singapore, pp. 397.

19. Ayers, RS and DW Westcot 1976 . Water quality for agriculture. FAO Irrigation and Drainage Paper 29, FAO, Rome. p. 97.

20. Hounslow AW 1995. Water Quality Data: Analysis and Interpretation. CRC Press LLC, Lewis Publishers, Boca Raton. pp. 40.

21. Barua S and MS Islam 2014. Water quality assessment of dug well water and its adjoining Buriganga river reach in the old Dhaka of Bangladesh. J. Asiat. Soc. Bangladesh, Sci. 40(2): 207-218.

( Manuscript received on 20 August, 2018; revised on 19 February, 2019 ) 